\title{
Two mathematical approaches to study the phosphorus eutrophication of a wetland in Puerto Rico
}

\section{Dos métodos matemáticos para estudiar la eutrofización por fósforo de un humedal en Puerto Rico}

DOI: http://dx.doi.org/10.17981/ingecuc.15.1.2019.06

Artículo de Investigación Científica. Fecha de Recepción: 19/07/2018. Fecha de Aceptación: 24/01/2019.

\author{
Marlio Paredes Gutiérrez \\ Universidad del Valle. Cali, (Colombia) \\ Arizona State University. Tempe, Arizona (Estados Unidos) \\ Universidad Francisco Gavidia. San Salvador, (El Salvador) \\ marlio.paredes@correounivalle.edu.co \\ Brenda Carolina Torres Velásquez \\ Universidad del Turabo. Gurabo, Puerto Rico (Estados Unidos) \\ torresb2@suagm.edu \\ Yashira Marie Sánchez Colón \\ Ponce Health Sciences University. Ponce, Puerto Rico (Estados Unidos) \\ ysanchez@psm.edu \\ Fred Charles Schaffner Gibbs \\ Universidad del Turabo. Gurabo, Puerto Rico (Estados Unidos) \\ fschaffner@suagm.edu
}

Para citar este artículo:

Marlio Paredes-Gutiérrez; Brenda Torres-Velásquez; Yashira Sánchez-Colón; Fred Schaffner-Gibbs "Two mathematical approaches to study the phosphorus eutrophication of a wetland in Puerto Rico", INGE CUC, vol. 15, no. 1, pp. 63-76, 2019. DOI: http://doi.org/10.17981/ingecuc.15.1.2019.06

\section{Abstract}

Introduction- Laguna Cartagena (LC), a wetland in Lajas, Puerto Rico, has been negatively impacted by nutrients, mainly phosphorus run-off from agricultural activities until the end of sugar cane cultivation in the late 1900s. This led to $\mathrm{P}$ concentration remain high at hypereutrophic state that was irremediable even after a 5 -fold reduction in source water nutrient concentration.

Objective- The main goal of this research paper is to apply two different mathematical approaches to assess the eutrophication level of a wetland in Puerto Rico.

Methodology- Grey Cluster Method (GCM) was used to classify LC's eutrophic state by applying the International and Chinese trophic standards and two parameters, Total Phosphorous (TP) and Total Nitrogen (TN). Mean TP and TN from LC consolidated bottom substrate and flocculence samples were used to classify LC. To address whether LC can recover, soluble reactive phosphorus (SRP) and TP from LC inlet, outlet, and center water samples were used to model (differential equation) the input and loss of phosphorus in $\mathrm{LC}$ and determine whether an equilibrium point exists. GCM analysis classified LC as a eutrophic wetland using the International standard and hypereutrophic using the chinese standard.

Results-Trophic state classification did not vary with use of consolidated bottom substrate versus flocculence samples. The differential equation model showed that SRP and TP levels within $\mathrm{LC}$ were higher than levels of SRP and TP entering LC, which could be caused by a nutrient recycling process within LC that may predict failure of remediation efforts. An equilibrium point was found at the eutrophic level, which means that even if there is a reduction in phosphorus input, there will not be a change in LC's eutrophic state.

Conclusions- Chinese trophic standard indicated LC was in a hypertrophic state. Similar results were found using the international standard. The differential equation model showed that LC is irreversible.

Keywords- Phosphorus dynamics; total phosphorus; soluble reactive phosphorus; total nitrogen; equilibrium point; eutrophication; hypereutrophication; grey cluster method.

\section{Resumen}

Introducción- Laguna Cartagena (LC), es un humedal en Lajas, Puerto Rico, que ha sido afectado negativamente por nutrientes, principalmente escorrentía de fósforo de las actividades agrícolas hasta el final del cultivo de la caña de azúcar a fines del siglo XX. Estas condiciones han propiciado que, la concentración de $\mathrm{P}$ permaneciera alta en un estado hipereutrófico, el cual era irremediable incluso después de una reducción de 5 veces en la concentración de nutrientes del agua fuente.

Objetivo- El objetivo principal de este artículo de investigación es aplicar dos métodos matemáticos diferentes para evaluar el nivel de eutrofización de un humedal en Puerto Rico.

Metodología- El Método de Agrupamiento de Grises (GCM) se usó para clasificar el estado eutrófico de LC aplicando los estándares tróficos internacional y chino y dos parámetros, Fósforo Total (TP) y Nitrógeno Total (TN). La media de TP y TN en el sustrato del fondo consolidado de LC y las muestras de floculencia se utilizaron para clasificar LC. Para analizar si LC puede recuperarse, se utilizó fósforo reactivo soluble (SRP) y TP a partir de muestras de agua a la entrada, salida y centro de LC para modelar (ecuación diferencial) la entrada y pérdida de fósforo en $\mathrm{LC}$ y determinar si existe un punto de equilibrio. $\mathrm{El}$ análisis GCM clasificó a la LC como un humedal eutrófico utilizando el estándar internacional e hipereutrófico utilizando el estándar chino. Resultados- La clasificación del estado trófico no presentó variaciones con el uso del sustrato de fondo consolidado versus las muestras de floculencia. El modelo de ecuaciones diferenciales mostró que los niveles de SRP y TP dentro de LC fueron más altos que los niveles de SRP y TP que entran en LC, lo que podría ser causado por un proceso de reciclaje de nutrientes dentro de LC que puede predecir el fracaso de los esfuerzos de remediación. Se encontró un punto de equilibrio a nivel eutrófico, lo que significa que incluso si hay una reducción en la entrada de fósforo, no habrá un cambio en el estado eutrófico de LC.

Conclusiones- El estándar trófico chino indicó que la LC estaba en un estado hipertrófico. Se encontraron resultados similares usando el estándar internacional. El modelo de ecuaciones diferenciales mostró que LC es irreversible.

Palabras clave- Dinámica del fósforo; fósforo total; fósforo soluble reactivo; nitrógeno total; punto de equilibrio; eutrofización; hipereutrofización; método de agrupamiento de grises. 


\section{INTRODUCTION}

Addition of nutrients is a major threat to wetland ecosystems. Nutrients, such as phosphorus (P) and nitrogen $(\mathrm{N})$, are most commonly added to these aquatic ecosystems through agricultural activities or soil erosion with run-off of fertilizers; but domestic effluent can impact the aqueous environment too [1][3]. By 2030, it is estimated that fertilizers use could exceed 135 million metric tons [4].

A high concentration of nutrients; primarily nitrogen $(\mathrm{N})$ and/or phosphorus $(\mathrm{P})$, in aquatic habitats, leads to an increase in plant production and algae bloom due to their role as the primary limiting nutrients in freshwater ecosystems [3], [5]-[7]. The vegetation eventually dies and decomposes resulting in depletion of oxygen in the water which affects fish, shellfish and all species that need oxygen dissolved in water to survive. High decomposition rates affect the biogeochemical cycle of $\mathrm{P}$ and $\mathrm{N}$, and increases water turbidity, color, and odor resulting in increased water quality problems [7]-[9]. Because of this, eutrophication affects not only wetland wildlife but also human populations that rely on these ecosystems [10].

Eutrophication is a very complicated process not only because of the effect of nutrient interaction within the water but also because of a nutrient's interrelated inputs into a wetland, the external input, and the nutrient recycling effects. Nutrients, after entering the wetland, can be trapped in the sediment (consolidated sediment and flocculent sediment lying overtop of the more consolidated sediment below) or accumulate in the biota, and later be released, causing an internal load of nutrients (known as internal recycling) [11]-[14]. Nutrient recycling contributes to an increase in productivity in aquatic ecosystems [15], [3]. It is important to mention that the longevity of internal loading will depend on the flushing rate, loading history, and chemical characteristics of the sediment [16], [12], [17], [14], [18]. Some lakes respond relatively fast to a reduction in the external phosphorus load, while in other cases, the chemical resistance that follows the reduction in nutrient input can take 10 or more years [19]. For example, in high trophic lakes, the release of phosphorus from soils can release phosphate to the water column similar to external sources [20], even after the reduction of external loads [21], [16], [12], [14]. The total phosphorus concentration (TP) of eutrophic and hypereutrophic lakes are between 30 to $100 \mu \mathrm{g} / \mathrm{L}(\mathrm{ppb})$ and $>100$ $\mu \mathrm{g} / \mathrm{L}$ (ppb), respectively [15]. Total phosphorus (TP) is the combination of soluble reactive phosphorus (SRP or orthophosphate), hydrolyzable and organic phosphorus. Soluble reactive phosphorus is the only form of $\mathrm{P}$ that autotrophs can assimilate [5]. Retention of nutrients within wetlands can be due to biological, chemical and physical processes, as well as the nutrient make-up and other wetland characteristics [22]. For example, nitrogen can be retained within an aquatic ecosystem by uptake by vegetation and due to dissimilatory nitrate reduction to ammonium (DNRA, $\mathrm{NO}_{3}{ }^{-}$to $\mathrm{NH}_{4}{ }^{+}$) when particulate matter (inorganic and organic nitrogen) becomes storage into the sediment [23]-[26], [15]. Total nitrogen (TN) is the combination of organic nitrogen (proteins and nucleic acids) and ammonium. In contrast, retention of phosphorus includes processes such as assimilation, phosphorus association with several elements forms complexes that act to limit the return of $\mathrm{P}$ to the water column, phosphorus lithification, and exchange processes between soil/sediment and the water column [21], [22], [19].

This cycle of retention and release of nutrients can prevent or affect the efficiency of restoration measures, and for that reason, the study of this phenomenon has become crucial in water resources management field [27]. To assess eutrophication, a methodology to classify wetlands by level of eutrophication is needed as current systems use nutrient-specific indexes without consideration of nutrient interactions. The ecosystem of Laguna Cartagena (LC) is a freshwater wetland suffered severe cultural eutrophication during the latter half of the $20^{\text {th }}$ Century.

Since all nutrients and their interactions affect the composition of a wetland, an index that considers phosphorus and nitrogen, the major limiting nutrients in freshwater aquatic ecosystems, will provide a better classification system [28]-[30], [5], [9], [15]. We sought to develop an index using these two nutrients which considers the interaction between them as they are both involved in several processes including photosynthesis, protein formation, and symbiotic nitrogen fixation.

In addition, to assessing the eutrophication state, understanding how the input, output, and recycling of nutrients correlate with the eutrophic state is critical to restoration efforts. Because phosphorus is the most studied nutrient involved in eutrophication, we choose to study the movement dynamics of phosphorus, that is, the amount entering, passing through, and leaving an aquatic ecosystem, and how those movements affect the eutrophic state. Due to the complex ecological response to nutrient movement dynamics, our model is given by a differential equation that considers the phosphorus concentration in the water column, the rate of phosphorus entry and loss from water, the maximum rate of recycling of phosphorus, and the phosphorus concentration at which recycling is half the maximum rate to explain the effect of phosphorus movement dynamics within LC on its eutrophic state. Two functions were obtained using this method: one to explain phosphorus entry and the other to explain the loss of phosphorus. We analyze these two functions to determine if a loss of phosphorus is less or greater than, or equal to phosphorus input; and if the phosphorus concentration can be controlled by reducing the amount of phosphorus entering the ecosystem. We used this method to evaluate if eutrophication in LC can be reversed, and if possible, at what phosphorus concentration. 


\section{Materials And methods}

Data for this study was obtained from the published literature [31]. In brief, LC which is located in Lajas, Puerto Rico (lat $18^{\circ} 01^{\prime} \mathrm{N}$, long $67^{\circ} 06^{\prime} \mathrm{W}$ ), was once a large freshwater wetland habitat of individual nesting, resident and migratory waterbirds. Over the last 65 years, it has decreased in area and become hypertrophic due to unnaturally high nutrient loading from neighboring agricultural activities. Even with a decrease in soluble reactive phosphorus (SRP) concentration in the source water from $1500 \mu \mathrm{g} / \mathrm{L}$ to $50-300 \mu \mathrm{g} / \mathrm{L}$ it has not been able to recover [31].

\section{A. Terminology}

Classification of wetlands according to its productivity can vary according to the environmental standards used by countries or regions. Those differences can be very subtle. For example, differences in chlorophyll levels are set at $1.0 \mathrm{mg} / \mathrm{L}$ in oligotrophic lakes to $2.0 \mathrm{mg} / \mathrm{L}$ in lower mesotrophic in some systems [32], and $1.7 \mathrm{mg} / \mathrm{L}$ and $4.7 \mathrm{mg} / \mathrm{L}$, respectively in others [15]. Categories used to classify wetlands according to productivity are described below:

Oligotrophic state. Oligotrophic lakes are characterized by a low concentration of nutrients, low algae biomass, low rates of decomposition, high clarity, and abundant hypolimnetic oxygen [15], [33]. Their deep photic zones may support cold-water fisheries [34], [35]. Oligotrophic lakes are usually stable because the internal load of phosphorus is low [3].

Eutrophic state. Eutrophic lakes are characterized by a high concentration of nutrients causing high fertility in terms of algae biomass. External supply of nutrients to aquatic ecosystems includes groundwater, rainfall, and atmospheric input, also known as point sources [36] and/or from urban and agricultural runoff, industrial sewage also known as nonpoint sources (EPA). Finally, nutrients can come from internal loading, through recycling from sediments [3].

Mesotrophic state. Mesotrophic lakes are characterized by a moderate concentration of nutrients and an intermediate level of productivity in terms of their algae biomass [36].
Classification of eutrophic lakes according to their response to phosphorus input reduction. In 1999, Carpenter, Ludwing and Brock developed a classification for eutrophic lakes based on their response to a reduction in phosphorus input. The categories are reversible, hysteretic, and irreversible. An eutrophic lake can be considered reversible if it presents an immediate recovery in trophic state, proportional to the reduction of phosphorus input into the lake [35]. A eutrophic lake can be considered hysteretic if it requires an extreme reduction in phosphorus input for a specific period to recover [35]. A eutrophic lake can be considered irreversible if recovery is not possible by reducing phosphorus input [35].

\section{B. Parameters}

To assess the eutrophic level of LC, Grey Clustering Method (GCM) with two trophic standards was used. The two trophic standards are: The International standard [15] and the Chinese standard [32]. The International standard uses three categories for classifying trophic states: oligotrophic, mesotrophic, and eutrophic (Table 1).

TABLE 1. InTERNATIONAL TROPHIC STANDARD.

\begin{tabular}{|c|c|c|c|}
\hline \multirow{2}{*}{$\begin{array}{c}\text { Evaluation } \\
\text { Index }\end{array}$} & \multicolumn{3}{|c|}{ Trophic Categories (mg/L) } \\
\cline { 2 - 4 } & Oligotrophic & Mesotrophic & Eutrophic \\
\hline TP & 0.008 & 0.0267 & 0.084 \\
\hline TN & 0.661 & 0.753 & 1.875 \\
\hline
\end{tabular}

Source: Wetzel [15].

The Chinese standard uses six categories: oligotrophic, lower mesotrophic, mesotrophic, upper mesotrophic, eutrophic, and hypereutrophic (Table 2). To analyze the dynamics of phosphorus within LC, the model from Carpenter, Ludwing and Brock [35] was adapted and used.

Total phosphorus (TP) was measured after Persulfate Digestion of unfiltered samples, followed by colorimetric SRP analysis (or Ascorbic Acid Method). Persulfate Digestion include the acid hydrolysis or oxidative digestion of the organic and hydrolyzable phosphorus [37] which liberates organic phosphorus as inorganic phosphate.

Table 2. Chinese eutrophication Standard.

\begin{tabular}{|c|c|c|c|c|c|c|}
\hline \multirow{2}{*}{$\begin{array}{c}\text { Evaluation } \\
\text { Index }\end{array}$} & \multicolumn{5}{|c|}{ Trophic Categories (mg/L) } \\
\cline { 2 - 7 } & Oligotrophic & $\begin{array}{c}\text { Lower } \\
\text { Mesotrophic }\end{array}$ & Mesotrophic & $\begin{array}{c}\text { Upper } \\
\text { Mesotrophic }\end{array}$ & Eutrophic & Hypereutrophic \\
\hline $\mathrm{TP}$ & 0.003 & 0.005 & 0.025 & 0.050 & 0.200 & 0.600 \\
\hline $\mathrm{TN}$ & 0.030 & 0.050 & 0.3000 & 0.500 & 2.000 & 6.000 \\
\hline
\end{tabular}

Source: Zhou and Xu [32]. 
Soluble inorganic phosphate was measured as orthophosphate or soluble reactive phosphorus (SRP) concentrations in water samples using the Ascorbic Acid Method, which is a molybdate blue colorimetric method using a UV-VIS spectrophotometer (Thermo Fisher Scientific, Genesys 20) to measure sample absorption at $880 \mathrm{~nm}$. By the Ascorbic Acid Method, the sample containing phosphorus is treated with a combined reagent of sulfuric acid, antimony potassium tartrate, ammonium molybdate and ascorbic acid [37].

All reagents used were ACS certified with an analytical grade. The brand of the ascorbic acid, sodium hydroxide (pellets) and potassium persulfate anhydrous used was Thermo Fisher Scientific. The brand of antimony potassium tartrate and ammonium molybdate used was Sigma-Aldrich and for the sulfuric acid used was Spectrum Chemical [31].

Nitrogen is present in natural waters as nitrate $\left(\mathrm{NO}_{3}^{-}\right)$, nitrite $\left(\mathrm{NO}_{2}^{-}\right)$, ammonia $\left(\mathrm{NH}_{3}\right)$ and organically bound nitrogen. To determine nitrite, it was used a Hanna Instruments kit; HI 764 Nitrite Ultra Low Range, applying he EPA Diazotization method 354.1 [38]. Diazotization is a colorimetric method, in which the nitrite is determined through formation of a reddish-purple azo dye produced at $\mathrm{pH} 2.0$ to 2.5 by coupling diazotized sulfanilamide with $\mathrm{N}$-(1naphthyl)-ethyl-enediamine dihydrochloride (NED dihydrochloride) [37].

To determine nitrate, it was used a Hanna Instruments kit; HI 93728 Nitrate Ion Specific Meter and Cadmium Reduction Method 353.2 [39]. The NO3 is reduced almost quantitatively to nitrite $\left(\mathrm{NO}_{2}^{-}\right)$in the presence of cadmium (Cd). This method uses commercially available Cd granules treated with copper sulfate (CuSO4) and packed in a glass column [37]. The $\mathrm{NO}_{2}^{-}$produced thus is determined by EPA Diazotization method 354.1 [38].

To determine ammonium, it was used he Hanna Instruments kit; HI 3824 Ammonia Test kit. The ammonia is determined by a colorimetric method. The Nessler reagent reacts with ammonia, under strong alkaline conditions, to form a yellow colored complex. An addition of an EDTA (Ethylenediaminetetraacetic acid) solution inhibits precipitation of calcium and magnesium ions [31].

Estimates of TP and TN were used to assess eutrophication, while TP and SRP were used to study the dynamics of phosphorus. All parameters were measured in milligram (mg) per liter (L). Data analysis and development of algorithms was done using Matlab.

\section{Data}

In Table 3, the average TP and TN by sample site and type of sample within LC is presented. Values represent the most current data according to the published literature.

Table 4 and Table 5 show the estimation values for parameters of the model proposed, using real data from LC. Data in Table 4 will remain constant through the model, while Table 5 shows the values of SRP and TP entering to LC. Data in Tables 4 and 5 was used altogether to run simulations.

Table 4. Parameter estimates for Phosphorus dynamics

\begin{tabular}{|c|c|c|}
\hline \multirow{2}{*}{$\begin{array}{c}\text { Parameters } \\
\times 10^{3}\end{array}$} & \multicolumn{2}{|c|}{ Estimates when using } \\
\cline { 2 - 3 } & $\mathrm{SRP}$ & $\mathrm{TP}$ \\
\hline$s$ & 0.6 & 0.4 \\
\hline$r$ & 74.0 & 609.7 \\
\hline$m$ & 189.9 & 721.3 \\
\hline
\end{tabular}

$s p=$ rate of loss of phosphorus; $r=$ maximum rate of recycling phosphorus; $m=$ mass or concentration of phosphorus for which reaches half of maximum value.

Source: Authors.

Table 5. Values of SRP and TP entering LC TO SIMULATE L-VALUES

\begin{tabular}{|c|c|c|}
\hline $\mathrm{L}$ (input) in $\mu \mathrm{g} / \mathrm{L}$ & SRP & TP \\
\hline Minimum & 127.2 & 566.4 \\
\hline Average & 190.5 & 863.9 \\
\hline Maximum & 286.8 & $2,117.5$ \\
\hline
\end{tabular}

$L=$ rate of phosphorus input.

Source: Authors.

\section{Grey System}

Grey system theory (GST) was developed in 1982 to study systems where available information is insufficient and/or there is a great deal of uncertainty in the data [40]-[42]. GST has been used in numerous areas of research including agricultural, economics,

TAble 3. Total phosphorus and nitrogen for Substrate And Flocculence SAMples taken In four LC Sites.

\begin{tabular}{|c|c|c|c|c|c|c|c|}
\hline \multirow{2}{*}{$\begin{array}{c}\times 10^{3} \\
(\mathrm{mg} / \mathrm{L})\end{array}$} & \multicolumn{4}{|c|}{ Consolidated bottom substrate samples } & \multicolumn{3}{|c|}{ Flocculence associated with floating islands } \\
\hline & $\begin{array}{l}\text { Western } \\
\text { shoreline }\end{array}$ & $\begin{array}{l}\text { Western } \\
\text { extreme }\end{array}$ & $\begin{array}{l}\text { Center } \\
\text { cattails }\end{array}$ & $\begin{array}{c}\text { Eastern } \\
\text { sector }\end{array}$ & $\begin{array}{l}\text { Western } \\
\text { extreme }\end{array}$ & Center cattails & Eastern sector \\
\hline $\mathrm{TP}$ & 700.0 & 800.0 & 900.0 & 700.0 & $1,100.0$ & $2,100.0$ & $1,600.0$ \\
\hline $\mathrm{TN}$ & $6,110.1$ & $4,024.3$ & $4,088.9$ & $4,287.7$ & $12,322.2$ & $7,052.4$ & $12,261.2$ \\
\hline
\end{tabular}

Source: Sánchez-Colón [31]. 
geology, ecology [43], and environmental research [43]-[46]. GST takes complete known (white) and unknown information (black) about a specific phenomenon, and finds a solution in levels of grey.

Grey clustering method (GCM) is a method based on the assumption that there are $n$-cluster objects, with $m$-cluster indexes that characterize them; and that there are $s$-different categories where they should be classified. Data for objects are presented in a matrix $X$ with dimension $m \times n$, where $x_{j i}$ is the $j$-th parameter value for the $i$-th object of data matrix, for $j=1, \ldots, m$ and $i=1, \ldots, n$. A matrix with standards by category is used and it is known as $\Lambda$; this matrix has a dimension of $m \times s$, and its elements are $\lambda_{j k}$, where $k=1, \ldots s$.

Algorithm for grey clustering method consists of five steps to classify object(s) into categories or groups. Steps consist of: 1) taking out the dimension of datasets (matrix of data and parameters); 2) using the whitenization weight function (WWF) to prepare data to be classified; 3) calculating the matrix weights; 4) calculating the clustering vector; and finally, 5) determining the Grey Score (GS), also referred as incidence degree value. The WWF is a function that uses known data to prepare incomplete data to be classified into categories.

GCM has two main goals: to assign each object into one category and determine the order of the relationship when two or more objects are classified in the same category. Steps are described as follows:

1. Change dimensional data into non-dimension data, for datasets of objects and trophic state standards. To do this, the average standard value method was used which consists of calculating the average of each parameter in the matrix of standards $\Lambda=\left(\lambda_{j k}\right)$ and then dividing each component of $\Lambda$ and of the matrix of data $X=\left(x_{j i}\right)$ by this average, now named "Correction Factor" $(C F)$. The correction factor consists of

$$
C F_{j}=\frac{\sum_{k=1}^{\mathrm{s}} \lambda_{j k}}{s},
$$

for each $j$, where $j=1, \ldots, m$ and $s=$ total of cluster for classification. Then, $C F_{j}$ will be applied to matrices $\Lambda$ and $X$. Transforming $\Lambda$ matrix

$$
\lambda_{j k}=\frac{\lambda_{j k}}{C F_{j}}
$$

for each $j$, where $j=1 \ldots m$ and transforming $X$ matrix

$$
x_{j i}=\frac{x_{j i}}{C F_{j}},
$$

for each $j$, where $j=1, \ldots, m$.
2. Apply the whitenization weight function $f_{j k}$, where $f_{j k}$ is the function applied to the $j$-th index or parameter attributed to the $k$-th grey classification. Whitenization weight function (WWF) of the $k$-th pollutant to the -th classification is denoted as $f_{j k}\left(x_{i j}\right)$. When the eutrophication level increase if the measure of parameter increase, WWF is defined as follow:

$$
\begin{gathered}
f_{j 1}(x)=\left\{\begin{array}{cc}
1, & x \in\left[0, \lambda_{j 1}\right] \\
\frac{\lambda_{j 2}-x}{\lambda_{j 2}-\lambda_{j 1}}, & x \in\left(\lambda_{j 1}, \lambda_{j 2}\right) \\
0, & x \in\left[\lambda_{j 2}, \infty\right) \\
f_{j k}(x)=\left\{\begin{array}{cc}
\frac{x-\lambda_{j(k-1)},}{\lambda_{j k}-\lambda_{j(k-1)}} & x \in\left(\lambda_{j(k-1)}, \lambda_{j k}\right] \\
\frac{\lambda_{j(k+1)}-x}{\lambda_{j(k+1)}-\lambda_{j k}}, & x \in\left(\lambda_{j k}, \lambda_{j(k+1)}\right) \\
0, & \left.x \in\left[0, \lambda_{j(k-1)}\right] \cup\left[\lambda_{j(k+1))}\right), \infty\right)
\end{array}\right. \\
f_{j s}(x)=\left\{\begin{array}{cc}
\frac{x-\lambda_{j(s-1)},}{\lambda_{j s}-\lambda_{j(s-1)}}, & x \in\left(\lambda_{j(s-1)}, \lambda_{j s}\right) \\
1, & x \in\left[\lambda_{j s}, \infty\right)
\end{array}\right. \\
0, & x \in\left[0, \lambda_{j s}\right]
\end{array}\right.
\end{gathered}
$$

3. Calculation of $\eta_{j k}$, matrix of cluster weight, where $j$-th is the index attributed to the $k$-th grey classification. Suppose that $\lambda_{j k}$ is the threshold of $k$ subclass (category) of $j$ index (parameter), then $\eta_{j k}$ calculation is as follow:

$$
\eta_{j k}=\frac{1 / \lambda_{j k}}{\sum_{j=1}^{m} 1 / \lambda_{j k}},
$$

where $k=1, \ldots, s$.

4. Calculation of clustering vector $\sigma_{i k}$. Clustering vector is defined as:

$$
\sigma_{i k}=\quad \sum_{j=1}^{m} f_{j k}\left(x_{i j}\right) \cdot \eta_{j k},
$$

where $i=1, \ldots, n$ and $k=1, \ldots, s$.

5. Determinate the incidence degree value to classify objects in grey classes. Incidence degree value is given by $\sigma_{i k^{*}}=\max _{1 \leq k \leq s}\left\{\sigma_{i k}\right\}$, and this value represents the allocation of object $i$ to the grey class $k^{*}$.

Ordering objects within a category using GCM. The final stage of GCM algorithm provides the incidence degree value or Grey Score (GS) for each object. Two scenarios can happen: first, all objects are classified in different categories, or second, two or more elements are classified at same category. 
In the second scenario, GS also provides the order relationship among the elements classified in same cluster. Ordering is provided in an ascending numeric scale within a specific category from lessto-more, e.g. less mesotrophic to more mesotrophic.

\section{F. Differential Equation Model}

To obtain the model, the principle of mass conservation is used. One of the fundamental laws of physics states that mass can neither be produced nor destroyed, that is, mass is conserved. Here is the amount of phosphorus inside the system, then $d p / d t$ is the phosphorus accumulation rate and by the principle of mass conservation we have

$$
\begin{gathered}
\left\{\begin{array}{c}
\text { Phosphorus } \\
\text { accumulation rate }
\end{array}\right\}=\left\{\begin{array}{c}
\text { Phosphorus } \\
\text { flux entering }
\end{array}\right\} \\
-\left\{\begin{array}{c}
\text { Rate of } \\
\text { phosphorus } \\
\text { production }
\end{array}\right\}
\end{gathered}
$$

which is the equation for mass balance [47].

The model, which was first analyzed by Carpenter, Ludwing and Brock [35], is given by the differential equation

$$
\frac{d p}{d t}=L-s p+r \frac{p^{q}}{m^{q}+p^{q}},
$$

where $p$ is the amount of phosphorus (mass or concentration) in water, $L$ is the rate of phosphorus input (mass or concentration), $s p$ is the rate of phosphorus loss per unit time $\left(\right.$ time $\left.^{-1}\right), r$ is the maximum rate of recycling phosphorus, mass or concentration per unit time (time-1) and $m$ is the mass or concentration of phosphorus at which recycling reaches half of maximum rate.

In equation (10) there is two important terms: recycling rate and loss of phosphorus. Recycling rate is the last term in equation and according limnologic studies, it behaves as a sigmoid function which shape will vary according to values of $q$

$$
r \frac{p^{q}}{m^{q}+p^{q}}
$$

Exponent represents the steepness of the recycling rate sigmoid function at its inflection point. Values of $q$ can range from 2 for a deep cold rate, to 20 for a shallow warm lake [48]. Larger values of $q$ give a steeper curve. $r$ represents the maximum rate of phosphorus recycling. Finally, $m$ is the concentration of phosphorus at which recycling reached is half its maximum rate.

The differential equation model contains the terms $L, s, r$ and $m$ that were estimated based first on SRP, and then on TP. This nomenclature is used for the purpose of having just a system of equations that provides answers for both TP and SRP.

Equilibrium points of our equation can be found when the linear term that represents losses of phosphorus (11) intersects with the curve that represents the input of phosphorus in the aquatic ecosystem (12). This interaction is represented in Figure 1 [35].

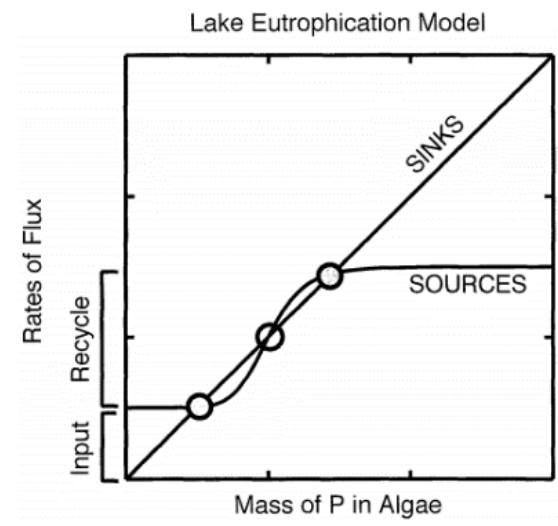

Fig. 1. Lake Eutrophication Model. Represents the rate of flux of phosphorus versus the mass of phosphorus in water. The straight line is given by equation (11), while the sigmoid curve is given by equation (12). Intersection points are the steady states. Open circles represent an unstable steady state while the shaded circles denote stable steady states. Source: Carpenter [35].

$$
\begin{gathered}
Q=s p \\
Q=L+r \frac{p^{q}}{m^{q}+p^{q}}
\end{gathered}
$$

Theoretically, a lake can have alternative states of oligotrophy or eutrophy, depending on values that parameters take. Hence, there can be up to three equilibrium points. The first type of equilibrium point is one in which the amount of phosphorus that enters the wetland $(L)$ is small, and it is an oligotrophic equilibrium point. If $L$ is a large value, then the intersection between curves (11) and (12) will be an eutrophic equilibrium point. The third type of equilibrium point is one in which $L$ is an intermediate value and it is an unstable equilibrium point that separates the domains of attraction of the other two equilibria [48].

In order to avoid complex calculation when doing the simulations, the model in (10) was rescaled. The process for rescaling was done as follows: first, set $p=m x$ and replace in (10)

$$
\frac{d(m x)}{d t}=L-s(m x)+r \frac{(m x)^{q}}{m^{q}+(m x)^{q}}
$$


Now, simplifying this equation we obtain

$$
m \frac{d x}{d t}=L-s m x+r \frac{x^{q}}{1+x^{q}}(14)
$$

Dividing by $m$ we have

$$
\frac{d x}{d t}=\frac{L}{m}-\frac{s m x}{m}+\left(\frac{r}{m}\right) \frac{x^{q}}{1+x^{q}} \text { (15) }
$$

Then, the equilibrium condition is given by the equation

$$
\frac{L}{m}-\frac{s m x}{m}+\left(\frac{r}{m}\right) \frac{x^{q}}{1+x^{q}}=0
$$

From where it can be said that

$$
L+r \frac{x^{q}}{1+x^{q}}=\operatorname{smx}
$$

Taking $r$ as common factor it is obtained the following equation

$$
\frac{L}{r}+\frac{x^{q}}{1+x^{q}}=\frac{s m x}{r}(18)
$$

Considering that parameters $r, s$ and $m$ are fixed, we set $a=L / r$ and $b=m s / r$, and we obtain the following equilibrium condition

$$
a+\frac{x^{q}}{1+x^{q}}=b x \quad(19)
$$

Finally, the trophic state of the wetland using this model was determined by plotting the curve $y=a+x^{q} /\left(1+x^{q}\right)$ that represents the input of phosphorus and the line $y=b x$ that represents the loss of phosphorus. Intersection points were calculated in order to determine if the state of the wetland is reversible. These points reflect the amount of phosphorus at which the wetland can be recovered.

\section{G. Simulations}

Simulations were run for the simplified model, after estimating the parameters $a$ and $b$, using the values in Table 4 and Table 5. Additionally, Table 6 and Table 7, contain the summary of values used for the simulation for parameters $L$ and $a$, when using SRP and TP.

Table 8 shows the different values that will be used for each parameter to run the simulation for the different sceneries to study. $b$ is a fixed value for the equation of loss of phosphorus. All values of will be used altogether for each $q$ value.

TAble 6. Estimation of Parameter $a$, Using Different VALUES OF SRP FOR THE $L$ PARAMETER

\begin{tabular}{|c|c|c|}
\hline SRP input & $\mathrm{L}$ & $a$ \\
\hline Min & 127.2 & 1.7 \\
\hline Average & 190.5 & 2.6 \\
\hline Max & 286.8 & 3.9 \\
\hline
\end{tabular}

Source: Authors.

Table 7. Estimation of Parameter $a$, USing Different VALUES OF TP FOR THE $L$ PARAMETER

\begin{tabular}{|c|c|c|}
\hline TP input & $\mathrm{L}$ & $a$ \\
\hline Min & 566.4 & 0.9 \\
\hline Average & 863.9 & 1.4 \\
\hline Max & $2,117.5$ & 3.5 \\
\hline
\end{tabular}

Source: Authors.

TABle 8 . VAlues for Parameters $a, b$ AND $q$ FOR SIMULATION OF SRP AND TP

\begin{tabular}{|c|c|c|}
\hline TP input & SRP & TP \\
\hline$a$ & $1.7,2.6,3.9$ & $0.9,1.4,3.5$ \\
\hline$b$ & 1.6 & 0.5 \\
\hline$q$ & $15-20$ & $15-20$ \\
\hline
\end{tabular}

Source: Authors.

\section{RESUlts AND DISCUSSION}

\section{A. Grey Clustering Method}

Two matrices are obtained after using the grey clustering method for classification (Table 9 and Table 10), both contain the incidence degree values (i.e., Grey Score (GS)) for LC using GCM and the International and Chinese Trophic Standard, respectively. The grey score is determined applying the most subjective principle, which states that the highest punctuation within clustering vector gives the corresponding classification for the sample (or wetland, or object to be classified). For example, using the international standard, flocculence samples from all sites were classified as eutrophic, with a grey score of 1 (Table 9). Similarly, when using the Chinese standard, flocculence samples for each sampling site within Laguna Cartagena were classified in the category of hypereutrophic, with a grey score of 1 (Table 10). A summary of results: GS for each LC site with the classification for both trophic standards are displayed in Table 11. 
Table 9. Incidence degree values for samples from Laguna Cartagena using International Trophic Standard

\begin{tabular}{|c|c|c|c|}
\hline Sample type and site & Oligotrophic & Mesotrophic & Eutrophic \\
\hline \multicolumn{5}{|c|}{ Consolidated bottom substrate } \\
\hline Western shoreline & 0 & 0 & 1 \\
\hline Western extreme & 0 & 0 & 1 \\
\hline Center cattails & 0 & 0 & 1 \\
\hline Eastern sector & 0 & 0 & 1 \\
\hline \multicolumn{7}{|c|}{ Flocculence by floating islands } \\
\hline Western extreme & 0 & 0 & 1 \\
\hline Center cattails & 0 & 0 & 1 \\
\hline Eastern sector & 0 & 0 & 1 \\
\hline
\end{tabular}

Source: Authors.

Table 10. Incidence degree values for samples from Laguna Cartagena using Chinese Trophic Standard

\begin{tabular}{|c|c|c|c|c|c|c|c|}
\hline Sample type and site & Oligotrophic & $\begin{array}{c}\text { Lower } \\
\text { mesotrophic }\end{array}$ & Mesotrophic & $\begin{array}{c}\text { Upper } \\
\text { mesotrophic }\end{array}$ & Eutrophic & $\begin{array}{c}\text { Hyper } \\
\text { eutrophic }\end{array}$ \\
\hline & & \multicolumn{5}{|c|}{ Consolidated bottom substrate } \\
\hline Western shoreline & 0 & 0 & 1 & 0 & \multicolumn{2}{|c|}{0} & 1 \\
\hline Western extreme & 0 & 0 & 1 & 0 & 0 & 1 \\
\hline Center cattails & 0 & 0 & 1 & 0 & 0 & 1 \\
\hline Eastern sector & 0 & 0 & 1 & 0 & 0 & 1 \\
\hline & & & \multicolumn{2}{|c|}{ Flocculence by floating islands } & \multicolumn{4}{|c|}{0} \\
\hline Western extreme & 0 & 0 & 0 & 0 & 0 & 1 \\
\hline Center cattails & 0 & 0 & 0 & 0 & 0 & 1 \\
\hline Eastern sector & 0 & 0 & 0 & 0 & 0 & 1 \\
\hline
\end{tabular}

Source: Authors.

Table 11. Results of Grey Clustering Algorithm Analysis for Samples from Laguna Cartagena by Standard

\begin{tabular}{|c|c|c|c|c|}
\hline & \multicolumn{2}{|c|}{ International standard } & \multicolumn{2}{c|}{ Chinese standard } \\
\hline Sample type and site & Grey score & Classification & Grey score & Hypereutrophic \\
\hline \multicolumn{5}{|c|}{ Consolidated bottom substrate } \\
\hline Western shoreline & 1 & Eutrophic & 1 & Hypereutrophic \\
\hline Western extreme & 1 & Eutrophic & 1 & Hypereutrophic \\
\hline Center cattails & 1 & Eutrophic & 1 & Hypereutrophic \\
\hline Eastern sector & 1 & Eutrophic & 1 & Hypereutrophic \\
\hline \multicolumn{7}{|c|}{ Flocculence by floating islands } & Hypereutrophic \\
\hline Western extreme & 1 & Eutrophic & 1 & Hypereutrophic \\
\hline Center cattails & 1 & Eutrophic & 1 & 1 \\
\hline Eastern sector & 1 & Eutrophic &
\end{tabular}

Source: Authors.

\section{B. Differential equation model}

Fig. 2, presents data from the simulation model for phosphorus in LC, using SRP. Fig. 3, presents data from the simulation model for phosphorus in LC, using TP. Analysis for the simulation using $q=19$ to $q=15$ for SRP and TP are shown in the Appendix.
In Fig. 2 and Fig. 3, external phosphorus input is plotted three times, simulating the input of phosphorus using the maximum, average and minimum value for SRP (or TP) in LC. In both figures, it can be observed that while the curve that represents the total load of phosphorus (SRP and TP) decreases, the linear function of the loss is always below the 


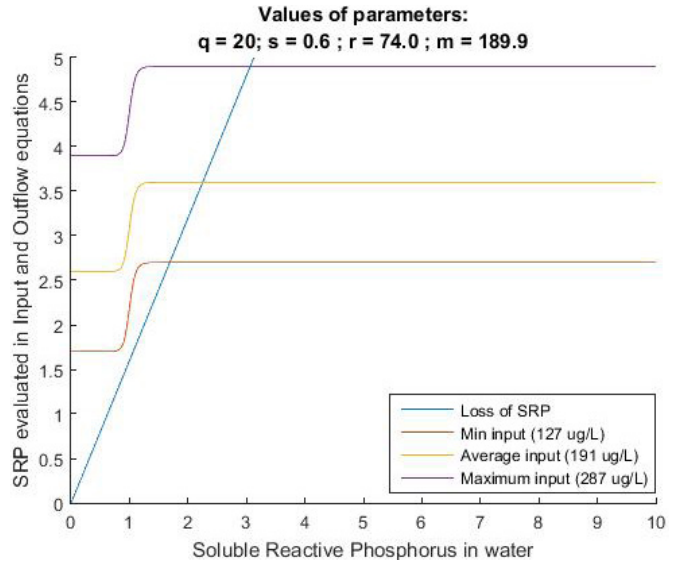

Fig. 2. Soluble reactive phosphorus dynamics in LC. Source: Authors.

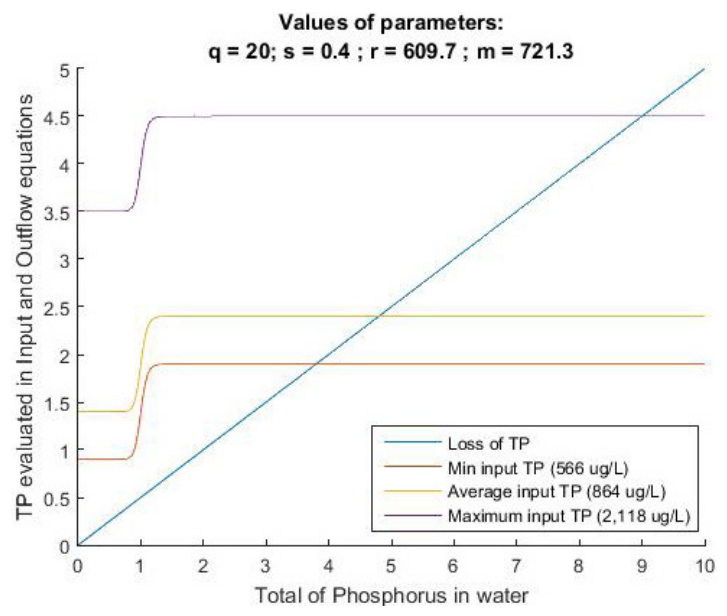

Fig. 3. Total phosphorus dynamics in LC Source: Authors.

phosphorus input curve (i.e., for any value of SRP or TP). In addition, even when using the minimum SRP value recorded and $\mathrm{LC}$ in $\mathrm{LC}$, the function for loss is below of the input function. As the function of loss is always below the function of input, the equilibrium point is eutrophic. From these results, we can infer that reducing the external input of phosphorus into the wetland is not enough to move the state of LC from eutrophic to mesotrophic or oligotrophic. Instead, the equilibrium point (i.e., intersection point between the two functions) is always in the eutrophic region.

\section{Conclusions}

Not only did we find that the equilibrium point of LC is always eutrophic regardless of the phosphorus input level, but we demonstrated that this is true when using all values of. If we consider that the most appropriate value for the estimate $q$ for LC is 20 (i.e., typical estimate for warm shallow wetlands like LC) it can be concluded that LC was not only in a eutro- phic state at the time of sampling, but that LC can be considered in an irreversible condition, since it is not possible to bring LC into an oligotrophic equilibrium by reducing phosphorus input.

If restoration of LC from eutrophic to oligotrophic state is desired, other methods should be used that help control the load of phosphorus within LC itself. Controlling the amount of external phosphorus that enters the system will not be sufficient. This can be done by controlling the recycling process, as well as what happens when phosphorus is released inside LC. One remediation method is to remove the soil from the bottom of the wetland, in order to force a change in its composition [49]. However, this method may also aggravate the problem, at least temporarily, by exposing a layer with a high content of nutrients that can be more readily released into the water column. This occurred when this remediation method was used in LC and lead to an increase in eutrophication [50].

Lastly, remediation efforts need to consider that in aquatic ecosystems dominated by non-N2-fixing cyanobacteria, it is important to control the input of both $\mathrm{P}$ and $\mathrm{N}$ to prevent the non-fixing bacteria from consuming phosphorus at the sediment-water interface and migrating to the surface to form blooms [51]-[52].

GCM is a classification technique widely used today mainly because of the accuracy of its results and the easiness in which the researcher is able to use data. In comparison to other methods, GCM allows for the analysis of a whole set of parameters chosen by researcher at the same time, without minimizing any of them. It also allows us to obtain a reproducible or accurate classification of the object.

GCM has as a main component the use of reference standards, chosen by the researcher, to classify objects into a trophic state. Since standards change between countries or areas, the GS change too, potentially assigning objects into a different category. Change in trophic classification can happen also if a new parameter is included in the analysis (e.g. dissolved oxygen). This allows the researcher to improve the accuracy of their results when they have more and/or new data to analyze.

Finally, the incidence degree value not only allows us to classify a body of water in a trophic state category, but it helps the researcher determine an order to the relationship among all bodies of water classified in the same category. For example, using Chinese trophic standard, all bottom substrate and flocculence samples presented levels of SRP that indicate LC was in a hypertrophic state. The GS obtained, which was one, implied that all the sites had the same phosphorus concentration. Something similar happened when we used the international standard, that is all sample types classified LC in the same category (i.e., eutrophic) and obtained the same GS of 1 . Two important conclusions can be drawn: 1.) LC is a wetland that underwent eutrophication and it was in a eutrophic state at the time of sample collection; and 2.) use of more precise trophic standards classified LC as hypereutrophic, a higher level of trophic state. 
Our results help us to better understand the trophic state of $\mathrm{LC}$ while proving that the trophic state is consistent regardless of trophic standard used. At the time of data collection, LC should be considered an irreversible lake. Restoration of LC from a severe the trophic state to a less severe one would require measures besides the reduction of phosphorus input.

\section{REFERENCES}

[1] S. R. Carpenter, N. F. Caraco, D. L. Correll, R. W. Howarth, A. N. Sharpley and V. H. Smith, "Nonpoint pollution of surface waters with phosphorus and nitrogen”, Ecological Applications, vol. 8, no. 3, pp. 559-568, Aug. 1998. https://doi.org/10.1890/10510761(1998)008[0559:NPOSWW]2.0.CO;2

[2] V. H. Smith, "Eutrophication of freshwater and coastal marine ecosystems: a global problem", Environmental Science and Pollution Research, vol.10, np.2, pp. 126-139, Mar. 2003. https://doi.org/10.1065/ espr2002.12.142

[3] S. R. Carpenter, "Eutrophication of aquatic ecosystems: Bistability and soil phosphorus", Proceedings of the National Academy of Sciences of Sciences of the United States of America, vol. 102, no. 29, pp. 10002-10005, Jul. 2005. https://doi.org/10.1073/pnas.0503959102

[4] P. M. Vitousek, J. Aber, R. Howarth, G. Likens, P. Matson, D. Schindler, W. Schlesinger and D. Tilman, "Human alteration of the global nitrogen cycle causes and consequences", Ecological Applications, vol. 7, no. 3, 737-750, Aug. 1997. https://doi.org/10.1890/10510761(1997)007[0737:HAOTGN]2.0.CO;2

[5] D. L. Correll, "Phosphorus: A rate limiting nutrient in surface waters", Poultry Science, vol. 78, no. 5, pp. 674-682, May. 1999. https://doi.org/10.1093/ $\mathrm{ps} / 78.5 .674$

[6] C. E. Lovelock, M. C. Ball, K. C. Martin and I. C. Feller, "Nutrient enrichment increases mortality of mangroves", PloS One, vol. 4, no. 5, p. e5600, May. 2009. https://doi.org/10.1371/journal.pone.0005600

[7] A. A. Ansari, S. S. Gill and F. A. Khan, "Eutrophication: threat to aquatic ecosystems", in Eutrophication: Causes, consequences and control, pp 143-170, Netherlands: Springer, 2010. https://doi.org/10.1007/978-90481-9625-8_7

[8] [EPA] Environmental Protection Agency (US), "Protecting Natural Wetlands: A Guide to Stormwater Best Management Practices", in: National Service Center for Environmental Publications (NSCEP), Washington (DC): Office of Water (US), 1996. Available in https://nepis.epa.gov/Exe/ZyPDF.cgi/200053GQ. PDF?Dockey=200053GQ.PDF. Accessed 08 Dec 2016.

[9] D. L. Correll, "The role of phosphorus in the eutrophication of receiving waters: a review", Journal of Environmental Quality, vol. 27, no. 2, pp. 261-266, Mar. 1998. https://doi.org/10.2134/ jeq1998.00472425002700020004x

[10] L. Volterra, M. Boualam, A. Ménesguen, J. Duguet, J. Duchemin and X. Bonnefoy. (2002). Eutrophication and Health. World Health Organization \& European Commission. Luxembourg. [Online]. Available in http:// www.y peka.gr/LinkClick.aspx?fileticket $=$ mb9Q7Nzw 5iI\%3D\&tabid=250\&language $=$ el-GR. Accessed 8 Dec 2016.

[11] E. D'Angelo, J. Crutchfield and M. Vandiviere, "Rapid, sensitive, microscale determination of phosphate in water and soil", Journal of Environmental Quality, vol. 30, no. 6, pp. 2206-2209, Nov. 2001. https://doi. org/10.2134/jeq2001.2206
[12] E. M. Bostic and J. R. White, "Soil phosphorus and vegetation influence on wetland phosphorus release after simulate drought", Soil Science Society of America Journal, vol. 71, no. 1, pp. 238-244, Jan. 2007. https:// doi.org/10.2136/sssaj2006.0137

[13] A. J. Smolders, L. P. Lamers, E. C. Lucassen, G. Van Der Velde and J. G. Roelofs, "Internal eutrophication: How it works and what to do about it - a review", Chemistry and Ecology, vol. 22, no. 2, pp. 93-111, Jan. 2007. https://doi.org/10.1080/02757540600579730

[14] K. R. Reddy, M. M. Fisher, Y. Wang, J. R. White and J. R. Thomas, "Potential effects of sediment dredging on internal phosphorus loading in a shallow, subtropical lake", Lake and Reservoir Management, vol. 23, no. 1, pp. 27-38, Jan. 2009. https://doi org/10.1080/07438140709353907

[15] R. G. Wetzel, Limnology: Lake and River Ecosystems. New York, USA: Elsevier Academic Press, 2001.

[16] M. M. Fisher and K. R. Reddy, "Phosphorus flux from wetland soils affected by long-term nutrient loading", Journal of Environmental Quality, vol. 30, no. 1, pp. 261-271, Jan. 2001. https://doi.org/10.2134/ jeq2001.301261x

[17] L. Bartoszek and J. A. Tomaszek, "Phosphorus distribution in the bottom sediments of the Solina-Myczkowce Reservoirs", Environment Protection Engineering, vol. 33, no. 2, pp. 25-33, 2007. Available http://epe.pwr. wroc.pl/2007/Bartoszek_2-2007.pdf

[18] L. E. Kinsman-Costello, "Effects of water level fluctuations on phosphorus, iron, sulfur, and nitrogen cycling in shallow freshwater ecosystems", PhD Dissertation, Michigan State University, East Lansing, MI, USA, 2012. Available in https://lter.kbs.msu.edu/pub/3226

[19] M. Sondergaard, P. J. Jensen and E. Jeppensen, "Retention and internal loading of phosphorus in shallow, eutrophic lakes", The Scientific World Journal, vol. 1, pp. 427-442, Aug. 2001. http://dx.doi.org/10.1100/ tsw. 2001.72

[20] J. J. González, B. Pérez and E. Fernández, "Analytical phosphorus fractionation in sewage sludge and sediment samples", Analytical and Bioanalytical Chemis try, vol. 381 , no. 4, pp. 873-878, Feb. 2005. https://doi. org/10.1007/s00216-004-2989-z

[21] B. Böstrom, J. M. Andersen, S. Fleisher and M. Jansson, "Exchange of phosphorus across the sediment-water in terface," Hydrobiologia, vol. 170 , no. 1, pp. 229-244, 1998. https://doi.org/10.1007/978-94-009-3109-1_14

[22] K. R. Reddy, R. H. Kadlec, E. Flaig and P. M. Gale, "Phosphorus retention in streams and wetlands: a review", Critical Reviews in Environmental Science and Technology, vol. 29, no. 1, pp. 83-146, Jun. 2010. https://doi.org/10.1080/10643389991259182

[23] S. P. Seitzinger, "Denitrification in freshwater and coastal marine ecosystems: Ecological and geochemical significance", Limnology and Oceanography, vol. 33, no. 4, pp. 702-724, Jul. 1988. https://doi.org/10.4319/ lo.1988.33.4part2.0702

[24] D. L. Saunders and J. Kalff, "Nitrogen retention in wetlands, lakes and rivers", Hydrobiologia, vol. 433, no. 1, pp. 205-212, Jan. 2001. https://doi. org/10.1023/A:1017506914063

[25] S. L. Whitmire and S. K. Hamilton, "Rapid removal of nitrate and sulfate in freshwater wetland sediments", Journal of Environmental Quality, vol. 34, no. 6, pp. 2062-2071, Nov. 2005. https://doi.org/10.2134/ jeq2004.0483

[26] A. J. Burgin and S. K. Hamilton, "Have we overemphasized the role of denitrification on aquatic ecosys tem? A review of nitrate removal pathway", Frontiers in the Ecology and the Environment, vol. 5, no. 2, pp. 89-96, Mar. 2007. https://doi.org/10.1890/1540 9295(2007)5[89:HWOTRO]2.0.CO;2 
[27] H. Wang, A. Appan and J. S. Gulliver, "Modeling of phosphorus dynamics in aquatic sediments: II-examination of model performance", Water Research, vol. 37, no. 16, pp. 3939-3953, Sep. 2003. https://doi. org/10.1016/S0043-1354(03)00305-1

[28] P. M. Vitousek and R. W. Howarth, "Nitrogen limitation on land and in the sea: How can it occur?" Biochemistry, vol. 13, no. 2, pp. 87-115, Jan. 1991. https:// doi.org/10.1007/BF00002772

[29] V. H. Smith, "Effects of nitrogen: phosphorus supply ratios on nitrogen fixation in agricultural and pastoral ecosystems", Biogeochemistry, vol. 18, no. 1, pp. 19-35, Feb. 1992. https://doi.org/10.1007/BF00000424

[30] K. Reddy, E. M. D'Angelo and W. G. Harris, "Biochemistry of Wetlands", in: Handbook of Soil Sciences, CRC Press, New York, pp. G89-G119, 2000.

[31] Y. M. Sánchez-Colón, "Effect of water level fluctuations and rainfall on phosphorus release and binding at a tropical freshwater wetland (Laguna Cartagena, PR)", M.S. Thesis, Dept. Ciencia y Tecnología, Univ. del Turabo, Gurabo, Puerto Rico, 2012.

[32] L. Zhou and S. Xu, "Application of Grey Clustering Method in eutrophication assessment of wetland", Journal of American Science, vol. 2, no. 4, pp. 53-58, 2006.

[33] [EPA] Environmental Protection Agency (US), "Nutrient Criteria Technical Guidance Manual: Rivers and Streams", in: Office of Water and Office of Science and Technology, 2008. Available in http://www.tampabay. wateratlas.usf.edu/upload/documents/NutrientCriteriaTGMRiversStreams.pdf Accessed 08 Dec 2016.

[34] W. K. Dodds, J. R. Jones and E. B. Welch, "Suggested classification of stream trophic state: distributions of temperature stream types by chlorophyll, total nitrogen and phosphorus", Water Research, vol. 32, no. 5, pp. 1455-1462, Mar. 1998. https://doi.org/10.1016/S00431354(97)00370-9

[35] S. R. Carpenter, D. Ludwig and W. A. Brock, "Management of eutrophication for lakes subject to potentially irreversible change", Ecological Applications, vol. 9, no. 3, pp. 751-771, Aug. 1999. https://doi.org/10.1890/10510761(1999)009[0751:MOEFLS]2.0.CO;2

[36] V. H. Smith, G. D. Tilman and J. C. Nekola, "Eutrophication: impacts of excess nutrient inputs on freshwater, marine, and terrestrial ecosystems", Environmental Pollution, vol. 100, no. 1, 179-196, Mar. 1999.

[37] American Public Health Association, American Water Works Association and Water Environment Federation, Standard Methods for the Examination of Water and Wastewater. 21st ed. Baltimore, Maryland, USA: Joint Editorial Board, 2005.

[38] [EPA] Environmental Protection Agency (US), National Pollutant Discharge Elimination System, Nitrite Method 354.1., 1971.

[39] [EPA] Environmental Protection Agency (US), National Pollutant Discharge Elimination System, NitrateNitrite Method 353.2., 1978.

[40] J. L. Deng, "Introduction to Grey System Theory", The Journal of Grey systems, vol. 1, no. 1, pp. 1-24, Nov. 1989.

[41] J. C. Huang, "The key factor of the internet information technology on the quality of life for the elderly: application of grey system theory", in: Special Issue on Intelligent Internet Systems. IEEE Advancing Technology for Humanity, no. 33, Dec. 2010. Available in http://ieeesmc.org/newsletters/back/2010_12/main_article2.html

[42] N. Slavek and A. Jović, "Application of Grey System Theory to Software Projects Ranking", Automatika, vol. 53, no. 3, pp. 284-293, Jan. 2017. https://doi. org/10.7305/automatika.53-3.80
[43] Y. Lin and S. Liu, "A historical introduction to grey systems theory", in: Systems, Man and Cybernetics, 2004 IEEE International Conference on, vol. 3, pp. 2403-2408, The Hague, Netherlands, 10-13 Oct. 2004. https://doi.org/10.1109/ICSMC.2004.1400689

[44] H. Kuang, D. M. Kilgour and K. W. Hipel, "Grey-bases PROMETHEE II with application to evaluation of source water protection strategies", Elsevier, Information Sciences, vol. 294, pp. 376-389, Feb. 2015. https://doi.org/10.1016/j.ins.2014.09.035

[45] B. Torres-Velasquez and M. Paredes, "Application of Grey Clustering Method to assess eutrophication in six freshwater Colombian wetlands", Realidad y Reflexion, vol. 18, no. 47, pp. 147-162, Jun. 2018.

[46] B. Torres-Velasquez, "Two different mathematical approaches to study eutrophication in wetlands: classification of trophic state using Grey System Theory to analyze phosphorus and nitrogen data, and the dynamics of phosphorus using differential equations", Ph.D. dissertation, Dept. Ciencia y Tecnología, Univ. del Turabo, Puerto Rico, Gurabo, 2016.

[47] R. E. Honrath, "Mass and Energy Balances", in CE251 Environmental Engineering Fundamentals. Michigan Tech. Univ., USA, 1995. Available in http://www.cee. mtu.edu/ reh/courses/ce251/251_notes_dir/node3.ht ml\#SECTION00030000000000000000

[48] F. Brauer and C. Castillo-Chávez, Mathematical Models in Population Biology and Epidemiology. New York, USA: Springer, 2012. https://doi.org/10.1007/978-14614-1686-9

[49] W. Liu, L. Zhang, J. Zhang, X. Liu, W. Huang, D. Huang and Z. Zheng, "Effects of modified sediment from a eutrophic lake in removing phosphorus and inhibiting phosphatase activity", Environmental Science and Pollution Research, vol 26, no.2, pp. 1723-1732, Nov. 2018. https://doi.org/10.1007/s11356-018-3754-8

[50] Y. M. Sánchez-Colón, "Identifying nonpoint sources of phosphorus $(\mathrm{P})$ and nitrogen $(\mathrm{N})$ pollution and $\mathrm{dy}$ namics, internal eutrophication and anoxia variability at a tropical freshwater wetland (Laguna Cartagena, Puerto Rico)", Ph.D. Dissertation, Dept. Ciencia y Tecnología, Univ. del Turabo, Puerto Rico, Gurabo, 2015.

[51] D. J. Conley, H. W. Paerl, R. W. Howarth, D. F. Boesch, S. P. Seitzinger, K. E. Havens, C. Lancelot and G. E. Likens, "Controlling eutrophication: nitrogen and phosphorus", Science, vol. 323, no. 5917, pp. 1014-1015, Feb. 2009. https://doi.org/10.1126/science. 1167755

[52] D. P. Hamilton, N. Salmaso and H. W. Paerl, "Mitigating harmful cyanobacterial blooms: strategies for control of nitrogen and phosphorus load", Aquatic Ecology, vol 50, no. 3, pp 351-366, Sept. 2016. https://doi. org/10.1007/s10452-016-9594-z

\section{APPENDIX}

This appendix includes figures (Fig. 4 to Fig. 15), summarizing findings for TP and SRP in Laguna Cartagena using q-parameters values ranging from 15 to 19. In each figure, recycling curves were developed using three phosphorus input values: minimum, maximum and average, and the linear function of the loss of phosphorus was plotted. 


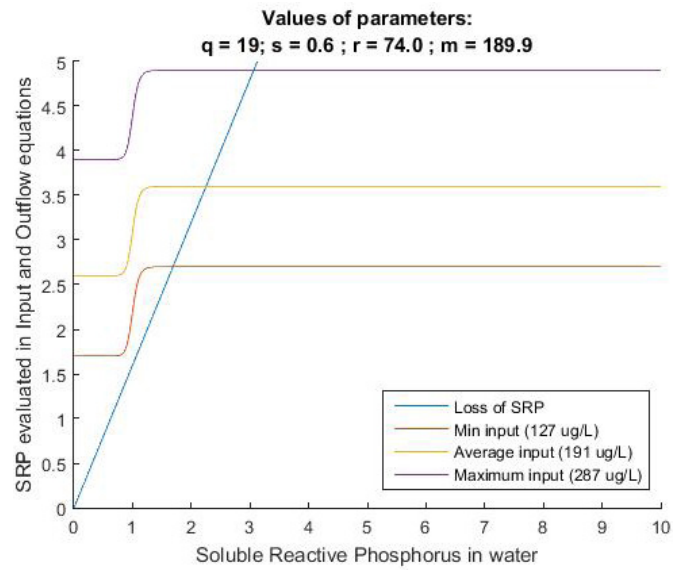

Fig. 4. Soluble reactive phosphorus input curves and loss linear function in Laguna Cartagena, when $q=19$. Source: Authors.

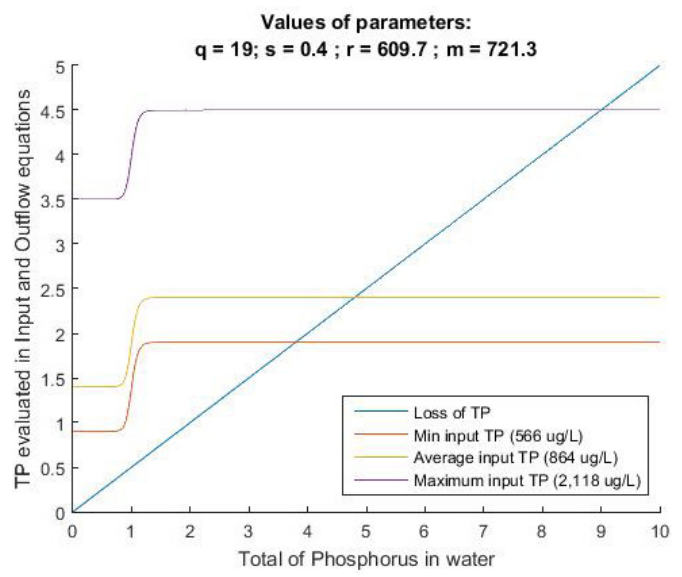

Fig. 5. Total phosphorus input curves and loss linear function in Laguna Cartagena, when $q=19$. Source: Authors.

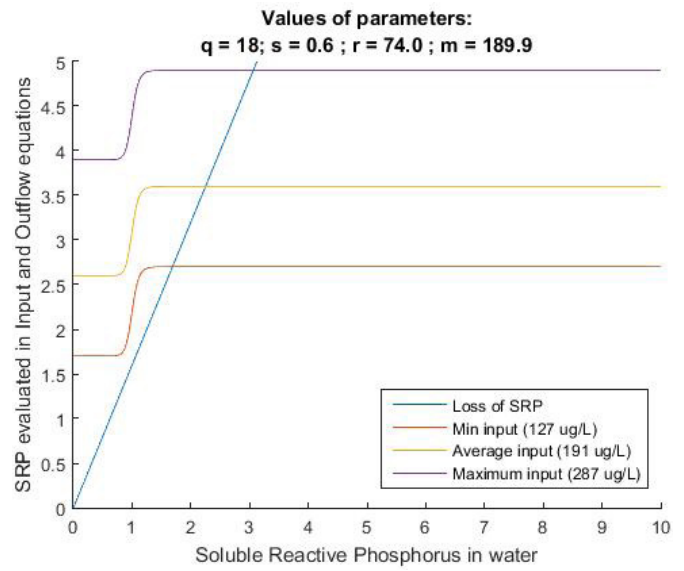

Fig. 6. Soluble reactive phosphorus input curves and loss linear function in Laguna Cartagena, when $q=18$. Source: Authors.

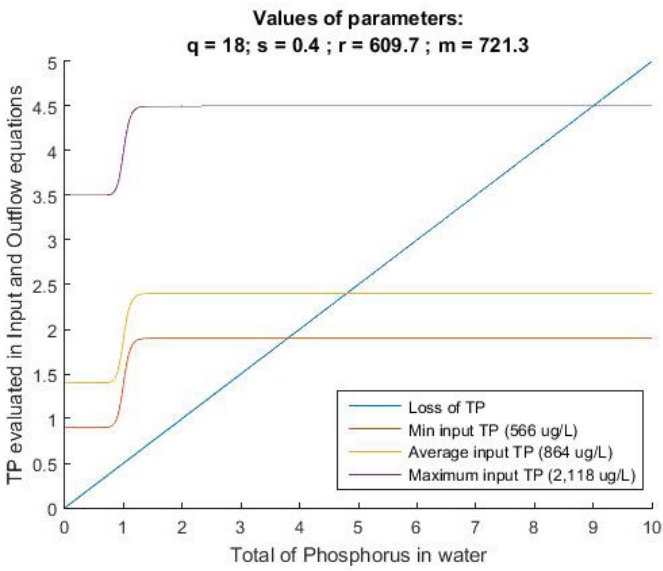

Fig. 7. Total phosphorus input curves and loss linear function in Laguna Cartagena, when $q=18$. Source: Authors.

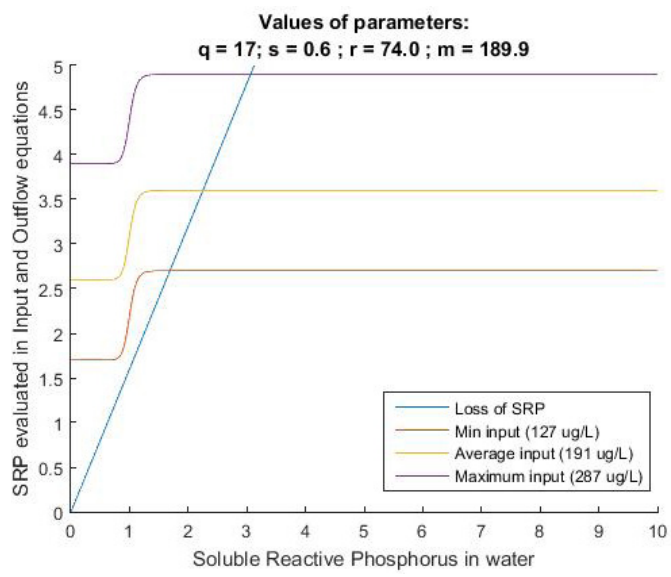

Fig. 8. Soluble reactive phosphorus input curves and loss linear function in Laguna Cartagena, when $q=17$. Source: Authors.

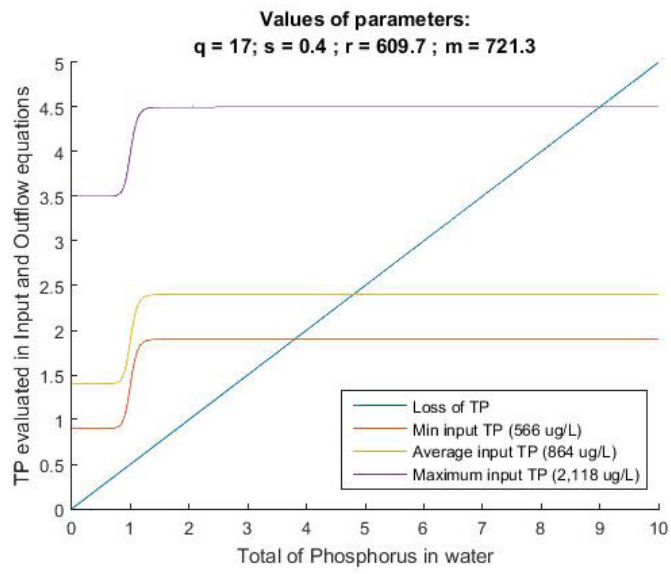

Fig. 9. Total phosphorus input curves and loss linear function in Laguna Cartagena, when $q=17$. Source: Authors. 


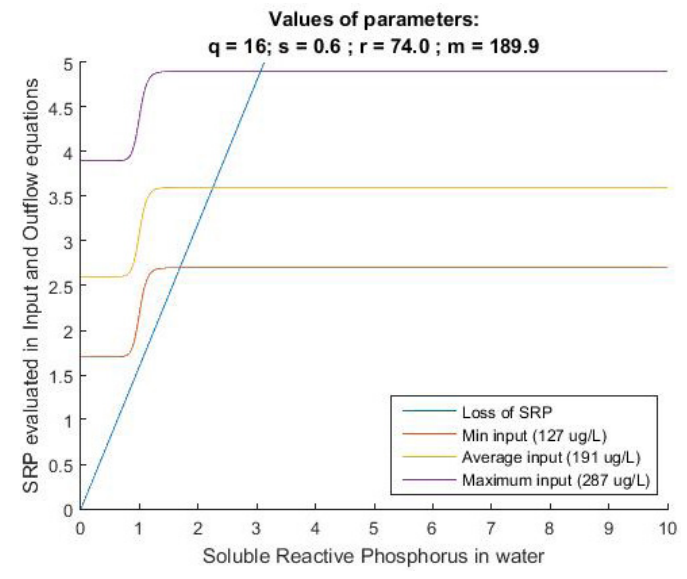

Fig. 10. Soluble reactive phosphorus input curves and loss linear function in Laguna Cartagena, when $q=16$ Source: Authors.

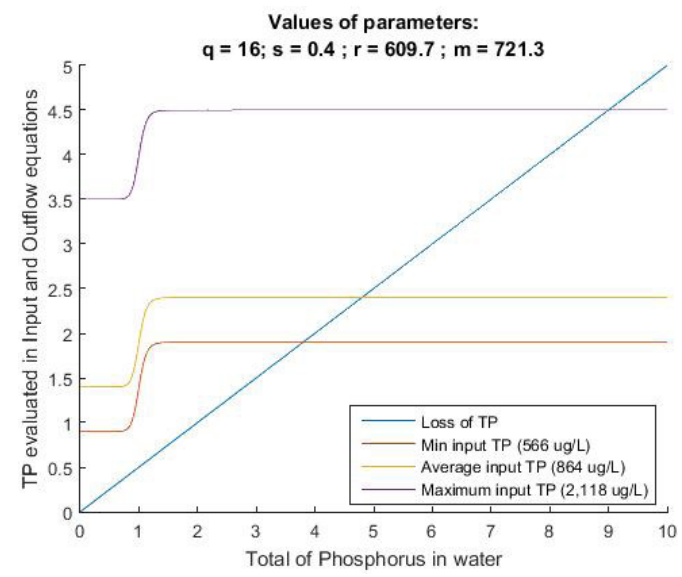

Fig. 11. Total phosphorus input curves and loss linear function in Laguna Cartagena, when $q=16$. Source: Authors.

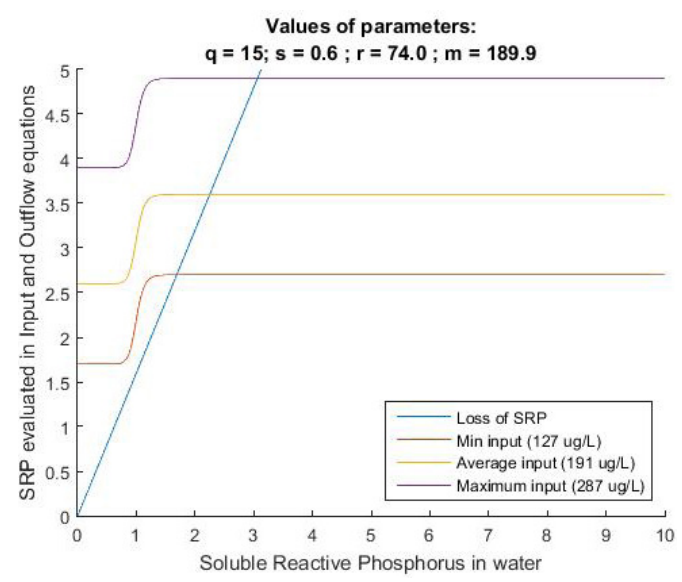

Fig. 12. Soluble reactive phosphorus input curves and loss linear function in Laguna Cartagena, when $q=15$. Source: Authors.

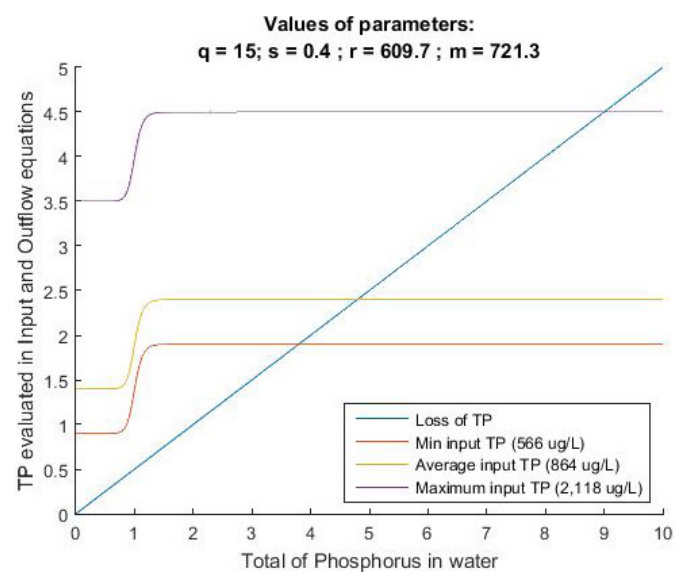

Fig. 13. Total phosphorus input curves and loss linear function in Laguna Cartagena, when $q=15$. Source: Authors.

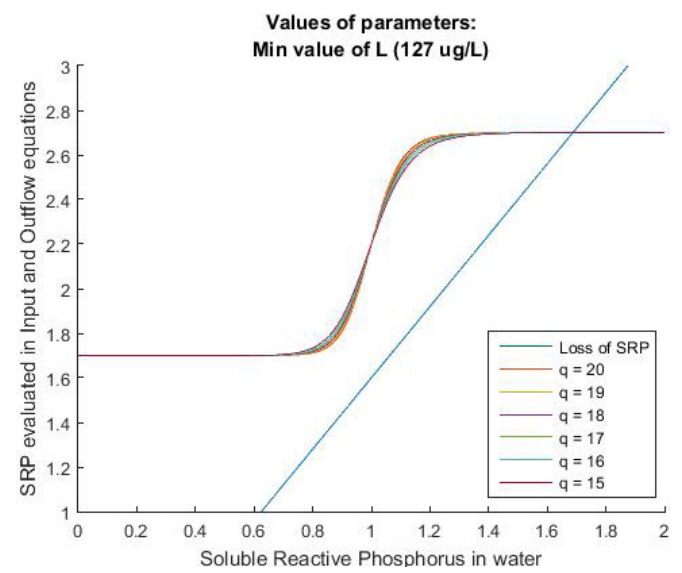

Fig. 14. Soluble reactive phosphorus input curves for $q=15: 20 ; L=$ minimum value of SRP input; and loss linear function in Laguna Cartagena.

Source: Authors.

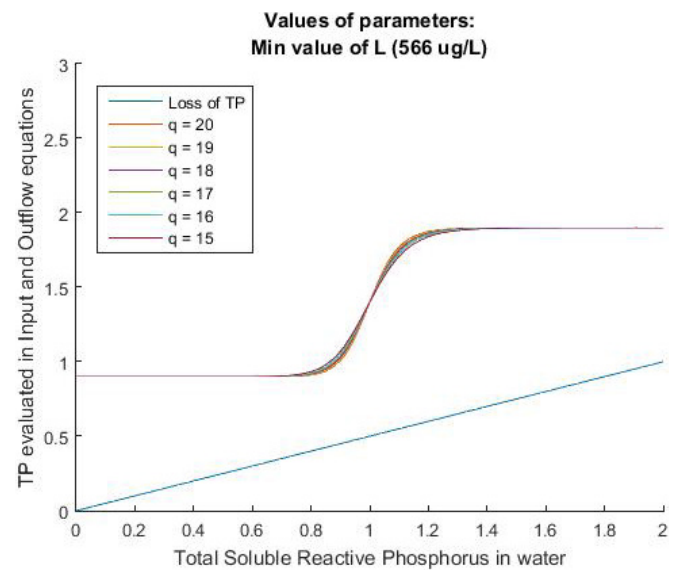

Fig. 15. Total phosphorus input curves for $q=15: 20 ; L=$ minimum value of TP input; and loss linear function in Laguna Cartagena. Source: Authors. 
Marlio Paredes-Gutiérrez received a bachelor's degree (1984) and a master's degree (1991) in mathematics from Universidad del Valle and his PhD Degree in Mathematics from State University of Campinas, Brazil, in 2000. From October 2014 to April 2015 he did a postdoctoral stay at Uppsala University in Sweden, working on an applied mathematics project. $\mathrm{He}$ is professor and researcher in the Department of Mathematics at Universidad del Valle, Cali, Colombia. His research interests include applied mathematics, mathematical modeling, differential geometry and combinatorics. https://orcid.org/0000-0002-9375-3743

Brenda Torres-Velásquez received the B.Eng. in Statistical Computing in 2005 from the Escuela Superior Politécnica del Litoral (Guayaquil, Ecuador); a master's degree in Statistics from Universidad de Puerto Rico ( Mayaguez, Puerto Rico) in 2009; and a doctoral degree in Environmental Sciences from Universidad del Turabo ( Gurabo, Puerto Rico) in 2017. His research interests include statistics applied to public health, epidemiology; disease outbreaks; environmental sciences; biology problems; water pollution; eutrophication
Yashira Sánchez-Colón is $\mathrm{PhD}$, Environmental Science, Universidad del Turabo, Gurabo, Puerto Rico. Her interests include the monitoring of aquatic ecosystems, especially nutrient concentrations and eutrophication in freshwater wetlands and issues related to both the Clean Water Act and Drinking Water Act. The prevention and assessment of health effects from environmental exposures are focal areas of Dr Sánchez' ongoing research interests. https://orcid.org/0000-0002-3129-561X

Fred Schaffner-Gibbs received the Ph.D. degree in environmental biology from University of Miami in 1988. He is Full Professor of Departamento de Ciencias Naturales y Tecnología, Universidad del Turabo. Gurabo, Puerto Rico, United States. His research interests include environmental issues, ecology and evolution, avian ecology and conservation biology. https://orcid.org/0000-0003-4877-5860 